\title{
Curcumin Enhanced Cutaneous Wound Healing by Modulating Cytokines and Transforming Growth Factor in Excision Wound Model in Rats
}

\author{
Raju Prasad $^{1}$, Dhirendra Kumar ${ }^{2}$, Vinay Kant ${ }^{2}$, \\ Surendra K. Tandan ${ }^{2}$ and Dinesh Kumar ${ }^{2}$ \\ ${ }^{1}$ Department of Veterinary Pharmacology \& Toxicology, Ranchi Veterinary College, \\ Birsa Agricultural University, Kanke (Jharkhand), Pin 834 006, India \\ ${ }^{2}$ Division of Pharmacology and Toxicology, IVRI, Izatnagar, Bareilly, UP \\ *Corresponding author
}

\begin{abstract}
A B S T R A C T
The present study was aim to evaluate the time-dependent wound healing effects of curcumin ointment $(0.3 \%)$ in excision wound model in albino rats. Thirty six acclimatized Keywords rats were equally divided into two groups and $\sim 2 \times 2 \mathrm{~cm}^{2}$ open excision-type wound was created in rats in Group I (control) and Group II (treated). Ointment base and $0.3 \%$ w/w curcumin ointment were topically applied once daily for 14 days in group I and group II rats respectively and healing parameters were analyzed on day 3, 7, 14 post-wounding. Progress in healing was evaluated by following parameters i.e. wound contraction, supported by photographic visualization, protein levels of TNF- $\alpha$, (Tumor necrosis factor$\alpha$ ), IL-10 (Interleukin-10), TGF- $\beta_{1}$ (Transforming growth factor- $\beta_{1}$ ) by ELISA test and immunohistochemistry of angiogenic marker protein CD-31 (Cluster of differentiation-31). The per cent $(\%)$ wound contraction was significantly $(\mathrm{P}<0.01)$ increased in curcumintreated group, as compared to control group on day 7,10 and 14. The application of curcumin markedly decreased the level of TNF- $\alpha$ on $3^{\text {rd }}$ day onwards whereas, the levels of IL-10 were increased significantly $(\mathrm{P}<0.01)$ in treated group from $3^{\text {rd }}$ day onwards. The levels of growth factors TGF- $\beta_{1}$ were also highly up-regulated on day 3,7 and 14 . On the day 14 , section of curcumin treated group had well formed capillary vessels lined by CD31 positive endothelial cells whereas, in control, ill formed capillary vessel scattered in immature granulation tissue were found. In conclusion, the curcumin ointment has promising wound healing potential in a time-dependent manner on topical application.
\end{abstract}

\section{Introduction}

Cutaneous wounds are physical injuries that result in an opening or break of the skin that causes disturbances in the normal skin anatomy \& function (Strodtbeck, 2001). It is an orchestrated series of events that includes inflammation, cell migration, cell proliferation, angiogenesis, matrix deposition and tissue remodeling (Gurtner et al., 2008; Braiman-Wiksman et al., 2007). There are many cytokines, growth factors and proteases including immune cells such as neutrophils, lymphocytes, monocytes, and dendritic cells, as well as endothelial cells, keratinocytes and fibroblast, which are closely involved in the wound healing process to complete normal tissue repair after damage (Singer and Clark, 1999). 
Curcumin, an active constituent of rhizomes of turmeric (Curcuma longa Linn.) (Zingiberaceae), is a well known indigenous medicine. Local application of turmeric is a household remedy in India for several conditions such as, skin diseases, insect bites and chicken pox (Nandkarni, 1976). Various studies reveals that curcumin plays important role in formation of granulation tissue, neovascularization and a faster reepithelialization of wound in both diabetic as well as hydrocortisone impaired wounds (Sidhu et al., 1999). Curcumin scavenges the free radical effectively and reduces the oxidative stress. The decreased oxidative stress lowers the inflammatory response and inhibits the expression of transcription gene NF-kB (Nuclear transcription factot-kB) (Bharti et al., 2003) by modulating through TNF- $\alpha$ (Tumour necrosis factor $-\alpha$ (Aggarwal, 2003). Curcumin also downregulates the expression of COX2, LOX, NOS, MMP-9, TNF- $\alpha$, cell surface adhesion molecules, and cyclin D1 (Aggarwal et al., 2004) which are important players of inflammatory and anti-inflammatory responses. Curcumin pretreatment enhances the synthesis of collagen, hexosamine, DNA, nitrite, and histologic assessment of wound biopsy specimens showed improved collagen deposition and an increase in fibroblast and vascular densities suggesting that curcumin may be able to improve radiation-induced delay in wound repair (Jagetia and Rajanikant, 2005). The use of herbal products in the treatment of wound may be of wide acceptability, better tolerance and inexpensive.

Although extensive work have been done on wound healing with curcumin in various formulation but curcumin $(0.3 \% \mathrm{w} / \mathrm{w})$ in ointment base containing hard paraffin, soft paraffin and lanolin has not yet been carried out. Based on above facts, the present study was designed to investigate the effect of curcumin ointment in exisional wound model in rats and its applicability in the wound healing for future therapy.

\section{Materials and Methods}

\section{Animals Used}

Thirty six healthy male Wistar rats (120$150 \mathrm{~g}$ ) (six week old) were procured from Laboratory Animal Resource Section, of IVRI, Izatnagar, Bareilly (UP). The rats were housed in divisional animal house in polypropylene cages at room temperature with a 12:12 light dark cycle. The experimental protocols involved in this study were approved by the Institutional Animal Ethics Committee of IVRI, Izatnagar, Bareilly (UP) and conforms to the guidelines for the Care and Use of Laboratory Animals published by the US National Institute of Health (NIH Publication No. 85-23, revised 1996). All the animals were acclimatized for a period of 7 days prior to the commencement of the experiments.

\section{Wound model}

The animals were anesthetized by an intraperitoneal (i.p.) injection of pentobarbitone sodium $(50 \mathrm{mg} / \mathrm{kg})$. Their dorsal surface was shaved and wiped with $70 \%$ ethanol. A $2 \times 2 \mathrm{~cm}^{2}\left(\sim 400 \mathrm{~mm}^{2}\right)$ full thickness open excision-type wound was created. Animals, after recovery from anaesthesia, were housed individually in properly disinfected cages.

\section{Experimental groups}

The experimental animals were divided in two groups, control and treated consisting of 18 rats each $(\mathrm{N}=18)$. Each group $(\mathrm{N}=18)$ was divided into three sub groups: $3^{\text {rd }}$ day $(n=6)$, $7^{\text {th }}$ day $(n=6)$, and $14^{\text {th }}$ day $(n=6)$ 
Group I (Control): Simple ointment base was applied topically once daily for 14 days. Group II (Treatment): Curcumin $(0.3 \%$ w/w) in ointment base was applied topically once daily for 14 days and the parameters were estimated on days 3, 7 and 14 post-wounding.

\section{Preparation of Ointment}

The Curcumin (Sigma, USA) (0.3\%) prepared in simple ointment base containing soft paraffin (90\%), hard paraffin (5\%) and lanolin $(5 \%)$ on ointment slab.

\section{Collection and preservation of tissue} samples

After the measurement of wound area, the animals were sacrificed at different time intervals with an overdose of diethyl ether. The granulation tissue were lifted and immediately divided into two parts. The one part was immediately preserved in $10 \%$ neutral buffer formalin for immunohistochemistry for angiogenic marker protein CD-31. The second part was snap frozen in liquid nitrogen and the tissue homogenate of the same was prepared with the help of motor homogenizer at $4{ }^{\circ} \mathrm{C}$ in icecold lysis buffer [100 mg tissue in $1 \mathrm{ml}$ lysis buffer: 1\% Triton $\mathrm{X}$ 100, $10 \mathrm{mM}$ phenylmethylsulfonyl fluoride (PMSF), 1 $\mathrm{mg} / \mathrm{ml}$ aprotinin and $1 \mathrm{mg} / \mathrm{ml}$ leupeptin in phosphate buffer saline (PBS) $\mathrm{pH}$ 7.4]. The homogenates were then incubated at $4^{\circ} \mathrm{C}$ for $30 \mathrm{~min}$ and centrifuged at $12,000 \mathrm{~g}$ for $10 \mathrm{~min}$ at $4{ }^{\circ} \mathrm{C}$. The aliquots of the supernatant were prepared and stored at $-80^{\circ} \mathrm{C}$ till further processing for ELISA.

\section{Wound contraction measurements}

The surface area of the wound was measured by tracing its contour using a transparent paper on days $0,3,7,10$ and 14 postwounding. The area (in square millimeters) within the boundaries of each tracing was determined planimetrically. The per cent (\%) wound contraction was derived by using the Wilson's formula as follow;

\section{0-day wound area - unhealed wound area}

Per cent wound contraction

X100

0-day wound area

Photographs of wound were also taken on days $0,3,7,10$ and 14 post-wounding by digital camera.

\section{ELISA Assay}

The protein levels of TNF- $\alpha$, IL-10 and TGF$\beta 1$ estimated by ELISA assay as per the ELISA kit manufacturer's instructions in granulation tissue lysates. The assay of IL-10 and TGF- $\beta 1$ (Genetix Biotech Pvt, Ltd) and TNF- $\alpha$ (Komabiotech Pvt Ltd) was done using a 96-well microtiter plate reader (photometry at $450 \mathrm{~nm}$ ). Each sample was used in duplicate and OD measurements were then verified against a standardized curve. The results were expressed as $\mathrm{pg} / \mathrm{ml} / 100 \mathrm{mg}$ of tissue.

\section{Immunohistochemistry of CD-31 (PECAM-1)}

The protein expression study of endothelial cell marker CD-31 as performed by immunohistochemistry on days 7 and 14 .

The pre-coated slide with 3-Amino propyl triethoxysilane (APES) (Sigma-Aldrich, USA). The tissue sections $(5 \mu \mathrm{m})$ were deparaffinized, rehydrated through graded 
alcohols. The antigen retrieval was performed with $10 \mathrm{mM}$ Sodium citrate buffer $\mathrm{pH}$ (6.0), heated in microwave oven for $10 \mathrm{~min}$ and cooled at room temperature for $20 \mathrm{~min}$. Blocking of endogenous peroxidase was done by incubating in $3 \%$ hydrogen peroxide in a humidified chamber for $20 \mathrm{~min}$ at $37^{\circ} \mathrm{C}$.

Non-specific bindings were blocked by incubating the tissue sections with $4 \%$ goat serum for 45 min. Section were covered with CD 31/ PECAM- 1 polyclonal antibodies (cat. sc-20356, Santa Cruz Biotechnology Inc., Santa Cruz, CA, USA) diluted at 1:100 ratio in donkey serum and incubated in humidified chamber for overnight at $4{ }^{\circ} \mathrm{C}$.

Specimens were incubated in 1-3 drops of biotinylated secondary antibody in humidified chamber for $30 \mathrm{~min}$. Then washed with PBS 3 times (5 min each) and were incubated for 30 min in 1-3 drops of HRP-streptavidin complex in humidified chamber. Sections were covered with freshly prepared HRP substrate (DAB) observed until light brown colour developed in sections.

Sections were then counterstained with Mayer's hematoxylin, dehydrated through graded alcohol, cleared into xylene, and mounted under glass coverslips. The sections were visualized for CD-31 antigens under light microscope (Olympus BX50 Tokyo, Japan).

\section{Statistical Analysis}

Results are expressed as mean \pm S.E.M. Data were analyzed by Bonferroni's post test using GraphPad Prism Version v4.0 (GraphPad Software, San Diego, CA).

Values on the same days of control and cucumin-treated groups were compared and probability level of less than $\mathrm{P}<0.05$ was considered statistically significant.

\section{Results and Discussion}

Effect of curcumin ointment on wound contraction

As shown in figure 1, the per cent (\%) wound contraction of control vs. treated animals was revealed significantly higher $(* * * \mathrm{P}<0.01)$ on day 3,7 and $14(11.26 \pm 0.92$ vs. $26.27 \pm$ $3.45),(44.12 \pm 3.54$ vs. $65.70 \pm 3.35)$ and $(84.80 \pm 0.10$ vs. $97.97 \pm 0.29)$ respectively. On day 10, it was also shown significantly higher $(* \quad \mathrm{P}<0.05)$ percent contraction in treated group as compared to control animals. Figure 2 illustrated representative photomicrographs of wound taken on day 0 , $3,7,10$ and 14 by digital camera.

\section{Effect of curcumin on the TNF- $\alpha$ cytokine level on day 3, 7 and 14 post-wounding}

The level of cytokine TNF- $\alpha$ in the granulation tissue is depicted in figure 3 . There is significant decreased $(* \mathrm{P}<0.05)$ in protein level of TNF- $\alpha$ on day 3 control versus treatment $(642.45 \pm 17.41$ $\mathrm{pg} / \mathrm{ml} / 100 \mathrm{mg}$ of tissue vs. $575.89 \pm 25.55$ $\mathrm{pg} / \mathrm{ml} / 100 \mathrm{mg}$ of tissue) and subsequently significant reduction $(* * \quad \mathrm{P}<0.01)$ was observed on day $7 \quad(173.99 \pm 6.46$ $\mathrm{pg} / \mathrm{ml} / 100 \mathrm{mg}$ of tissue vs. 121.12 \pm 5.53 $\mathrm{pg} / \mathrm{ml} / 100 \mathrm{mg}$ of tissue). On day 14, the result trends was also maintained $(91.07 \pm 1.88$ $\mathrm{pg} / \mathrm{ml} / 100 \mathrm{mg}$ of tissue $59.51 \pm 1.75$ $\mathrm{pg} / \mathrm{ml} / 100 \mathrm{mg}$ of tissue) control versus treated animals.

Effect of curcumin on the IL-10 cytokine level on day 3,7 and 14 post- wounding

ELISA assay of IL-10 has been summarized in figure 4 . The data revealed significant higher levels $(* * * \mathrm{P}<0.001)$ of IL-10 on day 3 $(1276.36 \pm 15.63 \mathrm{pg} / \mathrm{ml} / 100 \mathrm{mg}$ of tissue) in the curcumin-treated group, as compared with control group (1100.66 $25.30 \mathrm{pg} / \mathrm{ml} / 100 \mathrm{mg}$ 
of tissue). On day 7 and 14, the IL-10 cytokine level was also significantly higher (** $\mathrm{P}<0.01)$ in treated vs. control animals $(961.24 \pm 12.83 \mathrm{pg} / \mathrm{ml} / 100 \mathrm{mg}$ of tissue vs. $871.25 \pm 15.19 \mathrm{pg} / \mathrm{ml} / 100 \mathrm{mg}$ of tissue) and $(862.77 \pm 14.77 \mathrm{pg} / \mathrm{ml} / 100 \mathrm{mg}$ of tissue vs. $788.93 \pm 11.28 \mathrm{pg} / \mathrm{ml} / 100 \mathrm{mg}$ of tissue) respectively.

\section{Effect of curcumin on the TGF- $\beta 1$ cytokine level on day 3,7 and 14 post wounding}

The levels of growth factor, TGF- $\beta 1$ in granulation tissue has been presented figure 5 . There is significant $(* * * \mathrm{P}<0.001)$ increased level of TGF- $\beta 1$ on day $3(2686.34 \pm 50.88$ $\mathrm{pg} / \mathrm{ml} / 100 \mathrm{mg}$ of tissue), day 7 (2056.90 \pm $26.30 \mathrm{pg} / \mathrm{ml} / 100 \mathrm{mg}$ of tissue) and day 14 $(1481.22 \pm 21.55 \mathrm{pg} / \mathrm{ml} / 100 \mathrm{mg}$ of tissue $)$ while as control group reveals a level of $2158.27 \pm 57.49 \mathrm{pg} / \mathrm{ml} / 100 \mathrm{mg}$ of tissue, $1780.9 \pm 9.13 \mathrm{pg} / \mathrm{ml} / 100 \mathrm{mg}$ of tissue and $1281.38 \pm 29.92 \mathrm{pg} / \mathrm{ml} / 100 \mathrm{mg}$ of tissue respectively.

\section{Effect of curcumin on endothelial cell marker protein $\mathrm{CD}-31$ in tissue section}

Figure 6 depicts immunohistochemistry for the endothelial cell marker protein CD-31 of control and curcumin treated tissue section on day 7 and 14. As shown in figure 6, tissue section of control group, a very few positive endothelial cells (brown colour) seen whereas newly formed capillaries lined by CD-31 positive endothelial cells disperse within the immature granulation tissue was present in curcumin treated group on day 7. On the day 14, section of curcumin treated group showing more neo-vascularization and well formed capillary vessels lined by CD-31 positive endothelial cells whereas in control, ill formed capillary vessels scattered in immature granulation tissue were found.

Wound healing is complex series of processes that results in the contraction and closure of the wound and restoration of functional barrier (Hunt et al., 2000). There are many cytokines, growth factors and proteases which are closely involved in wound healing process to complete normal tissue repair after damage (Singer and Clark, 1999). A therapeutic agent selected for the treatment of wounds should ideally improve one or more phases of healing without producing deleterious side effects. Curcumin, an important active principle of turmeric (Curcuma longa), has been proved to promote wound healing in various wound models (Sidhu et al., 1998, 1999, 2002). In this study, the per cent contraction of wound was significantly higher in treated animals which are in agreement with other previous workers. During granulation tissue formation, as contraction proceeds and resistance increases, fibroblasts differentiate into myofibroblasts (Desmouliere et al., 1993) which is responsible for early closure of wound.

Hasten the wound healing process without microbial infection is the prime importance for any wound healing experiment. In this study, it has been shown from wound photographs at different time intervals, a better healing in the curcumin treated animals was observed as compared to control animals. Presence of optimal inflammation is essential for proper wound healing but pain and swelling accompanying excessive inflammation may cause agony to the patient (Dudhgaonkar, 2004). Decreased oxidative stress lowers the inflammatory response and inhibits the transcription of NF-kB. Reduced expression of NF-kB (Bharti et al., 2003) leads to the low gene expression of SOD (superoxide dismutase) enzyme. This is because curcumin scavenges the radical effectively and reduces the oxidative stress. Curcumin incorporated collagen matrix treatment showed increased wound reduction, enhanced cell proliferation and efficient free radical scavenging as compared with control 
and collagen treated rats (Gopinath et al., 2004). The levels of TNF- $\alpha$ cytokine decreased significantly on day 3,7 and 14 post wounding whereas the level of IL-10 cytokines was increased significantly in curcumin treatment as compare with control. This results in agreement that elevation of IL10 can down-regulate TNF- $\alpha$ production in macrophage leading to increased wound healing (Ribbons et al., 1997).

Fig.1 Percentage of wound closure rate on day 3, 7, 10 and 14 post wounding of curcumin treated groups as compared to control group $(* * \mathrm{P}<0.01, * * * \mathrm{P}<0.001$ significant

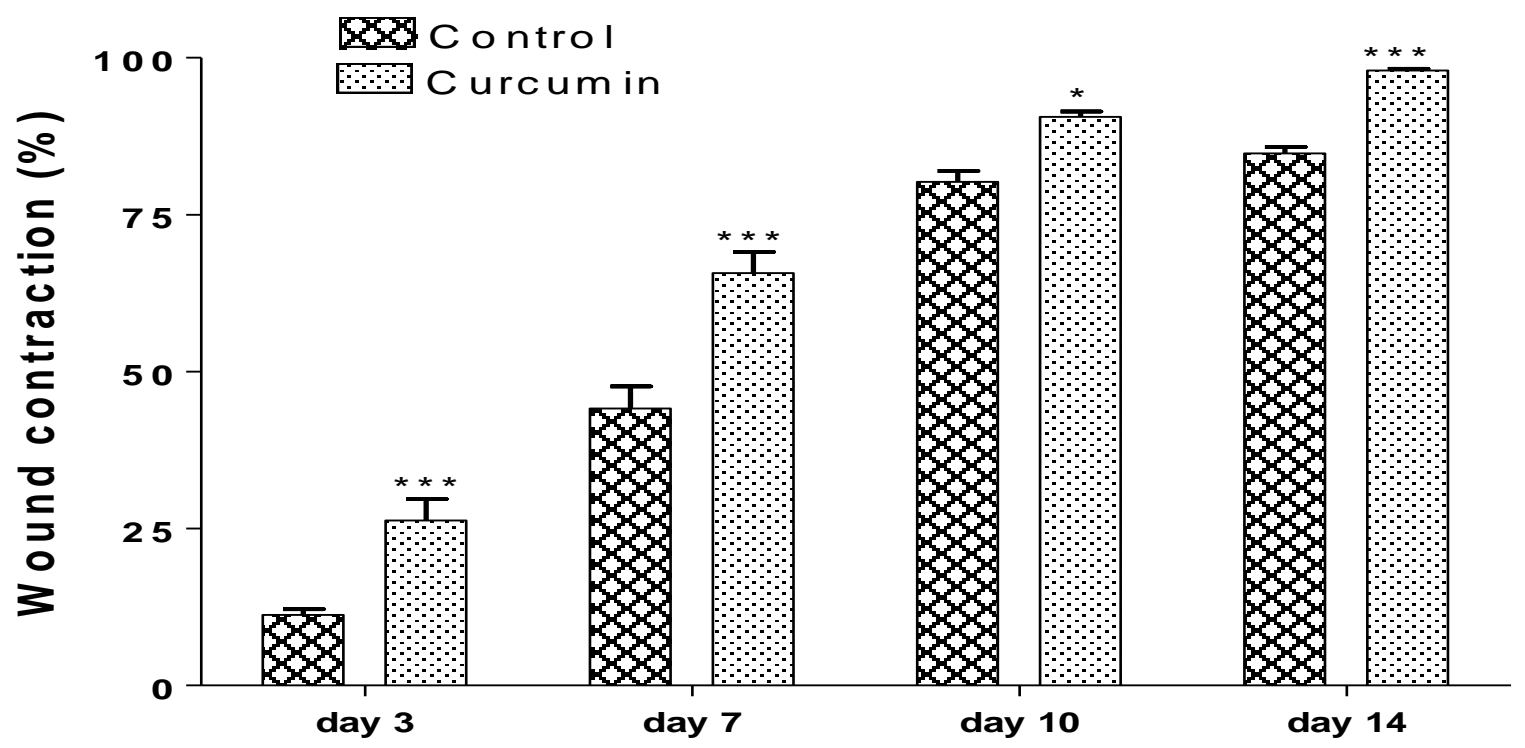

Fig.2 Representative pictures showing wound closure of control and curcumin

$(0.3 \%)$ treated rats on day $0,3,7,10$ and 14 post wounding
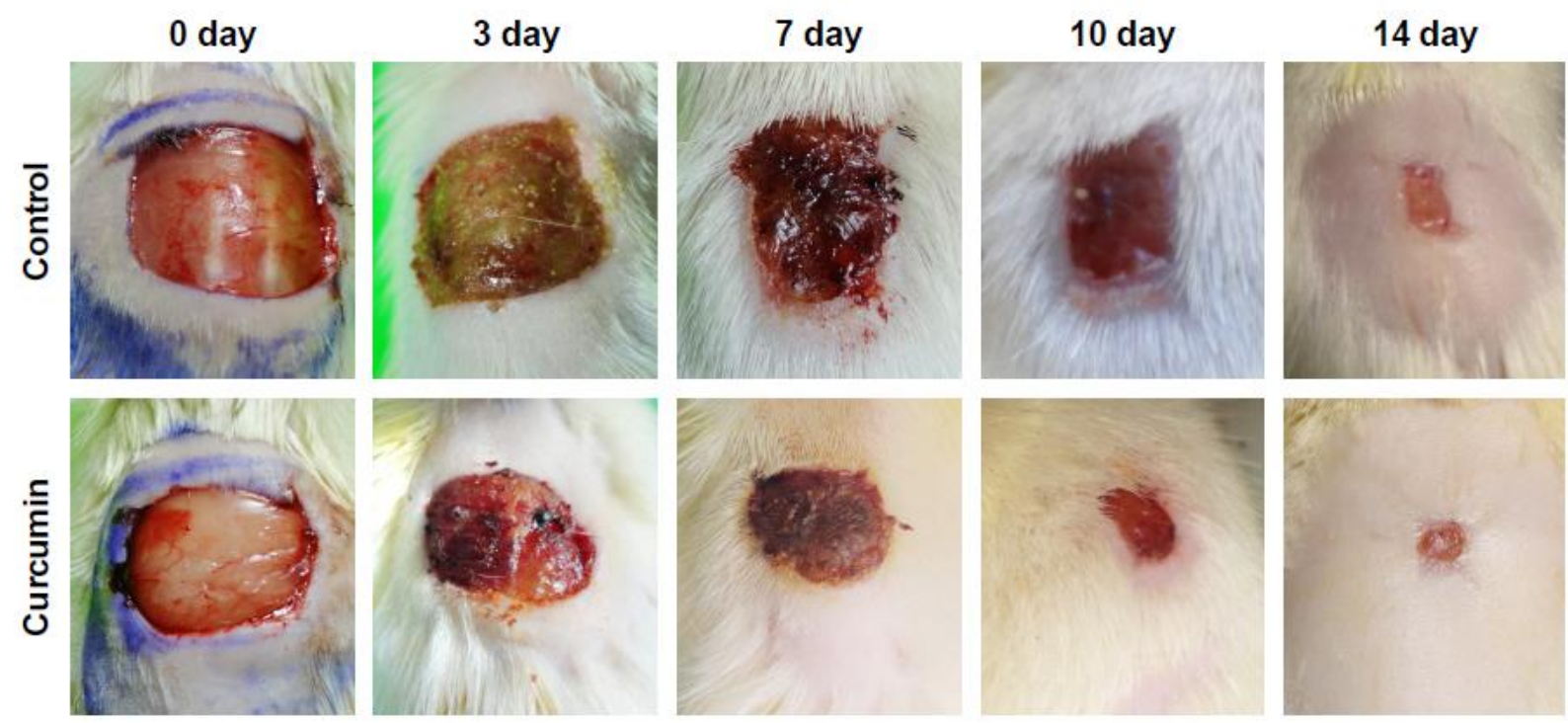
Fig.3 Effects of topical application of curcumin (0.3\%) on protein levels of TNF- $\alpha$

in granulation tissue on days 3, 7 and 14 post-wounding. Data are expressed as mean $\pm \mathrm{SEM}, \mathrm{n}=6(* \mathrm{P}<0.5, * * \mathrm{P}<0.01)$

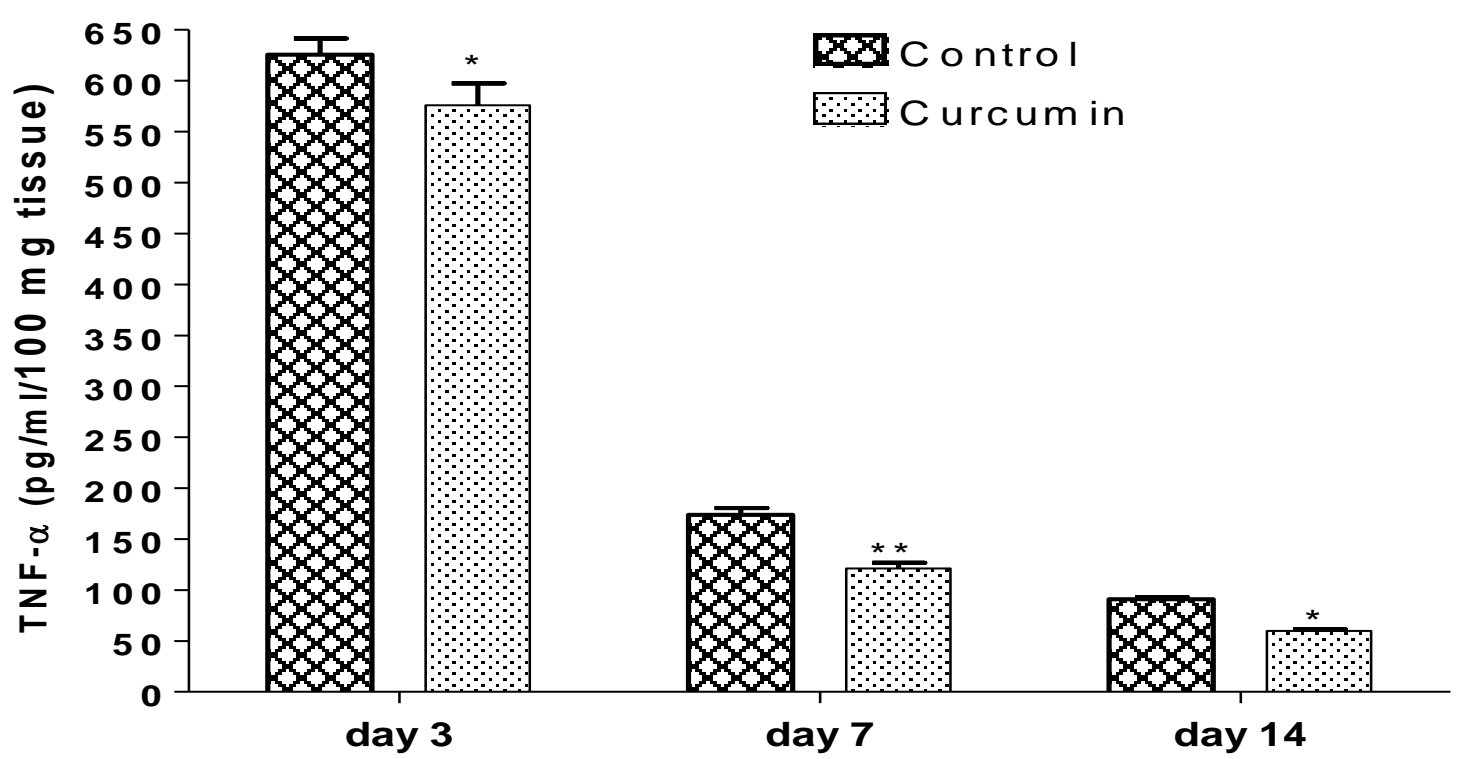

Fig.4 Effects of topical application of curcumin (0.3\%) on protein levels of IL-10 granulation tissue on days 3, 7 and 14 post-wounding. Data are expressed as mean $\pm \mathrm{SEM}, \mathrm{n}=6(* * \mathrm{P}<0.01, * * * \mathrm{P}<0.001)$

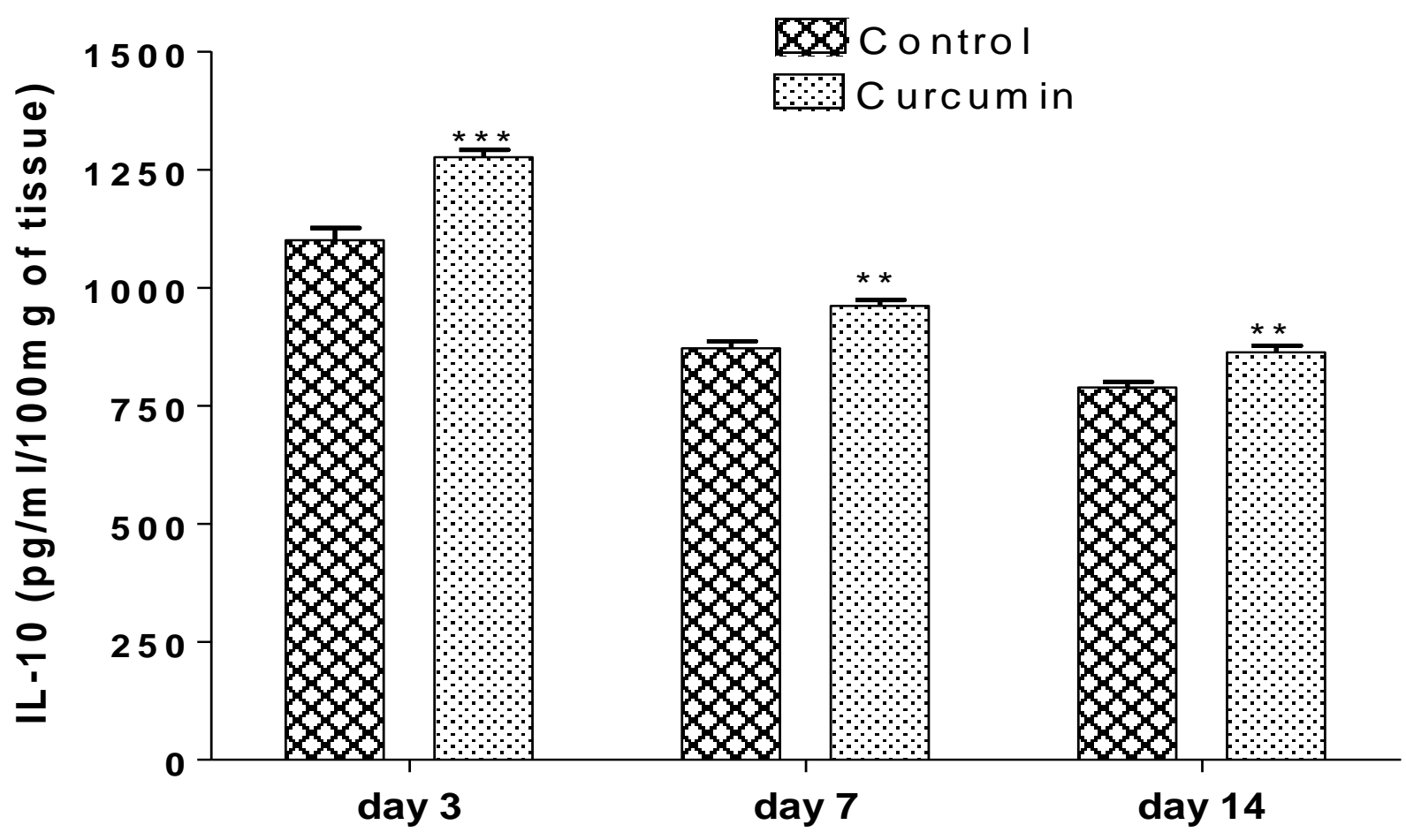


Fig.5 Effects of topical application of curcumin (0.3\%) on protein levels of TGF- $\beta 1$ in granulation tissue on days 3, 7 and 14 post-wounding. Data are expressed as mean $\pm \mathrm{SEM}, \mathrm{n}=6(* * \mathrm{P}<0.01, * * * \mathrm{P}<0.001)$

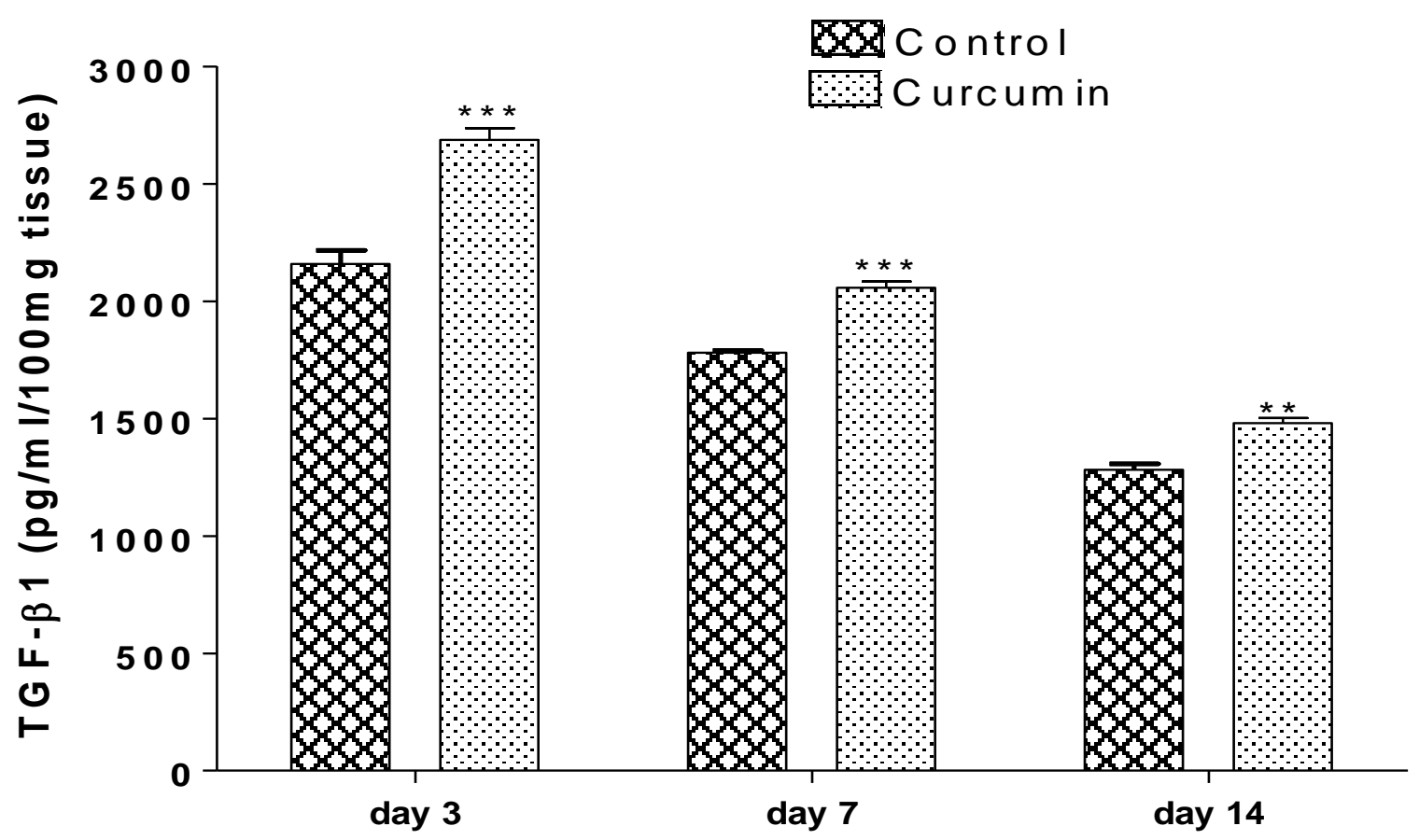

Fig.6 Effects of topical application of curcumin (0.3\%) on endothelial cells marker (CD-31) protein expression by immunohistochemistry in tissue section on day 7 (A, C) and $14(\mathrm{~B}, \mathrm{D})$ in control and treated animals. Brown colour shows the expression of CD-31 protein in blood vessels
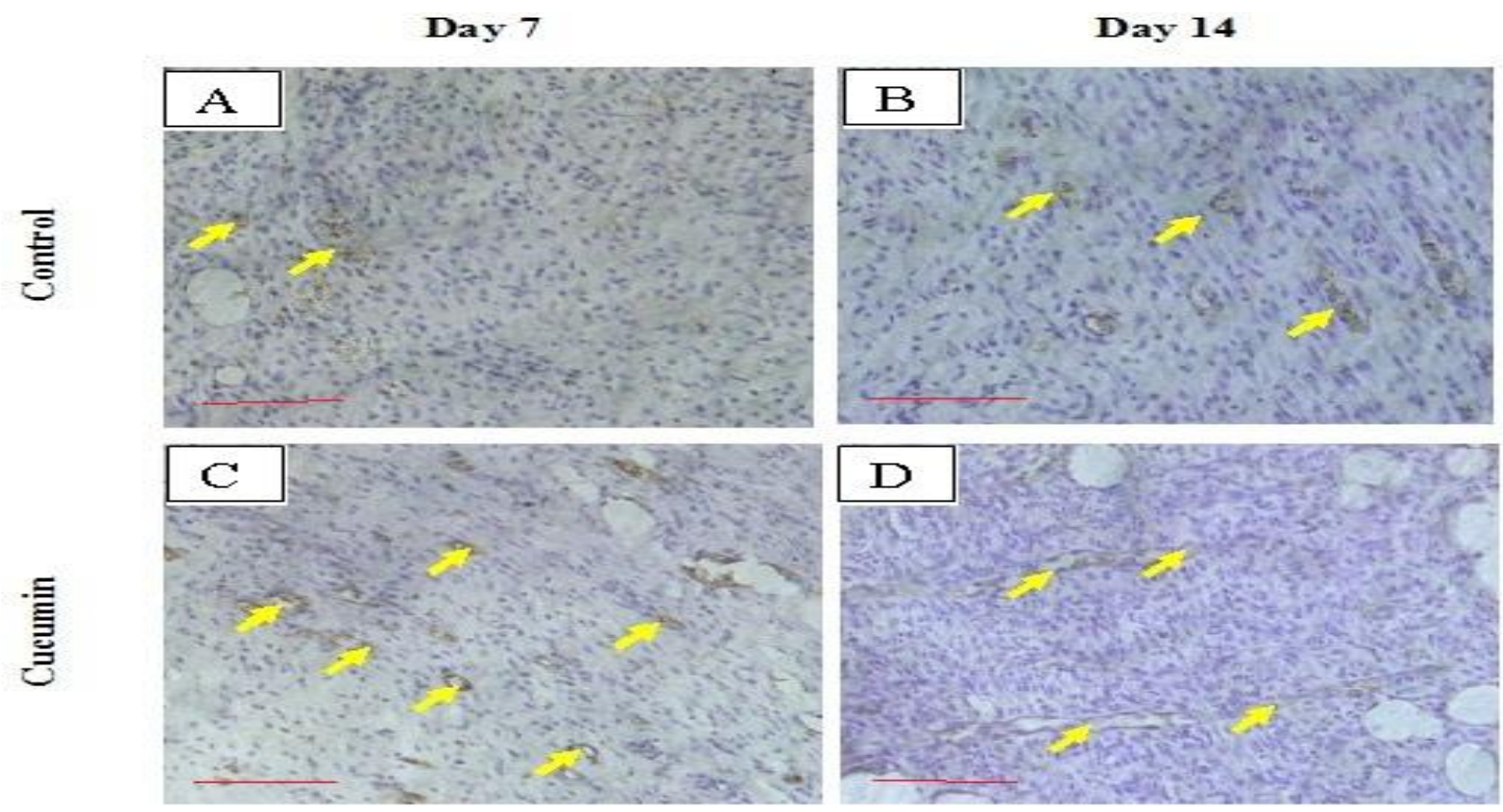
Curcumin blocked the activation of NF-kB by TNF- $\alpha$ (Kim et al., 2007). The expression of TNF- $\alpha$ is regulated by NF-kB (Aggarwal, 2003). Curcumin downregulated the expression of COX2, LOX, NOS, MMP-9, TNF- $\alpha$, cell surface adhesion molecules, and cyclin D1 (Aggarwal et al., 2004). TGF- $\beta 1$ is important in wound healing as it stimulates the expression of fibronectin $(\mathrm{FN})$ and collagen by fibroblasts and increases the rate of formation of granulation tissue in vivo (Varga et al., 1987; Quaglino et al., 1990).

In present study demonstrated that on topical application of curcumin ointment, the levels of TGF- $\beta 1$ growth factors significantly increased on day 3, 7 and 14 as compared with control (Fig. 5) wounds favours more collagen synthesis, well formed granulation tissue and blood vessels in the treated samples. Sidhu et al., 1999, had also reported that the curcumin treatment led to an increased formation of granulation tissue including greater cellular content, neovascularization and a faster reepithelialization of wound in both diabetic as well as hydrocortisone impaired wounds by regulating the expression of TGF- $\beta 1$, its receptors and nitric oxide synthase during wound healing (Mani et al., 2002).

Angiogenesis during wound repair serves the dual function of providing the nutrients required by the healing tissue and contributes to the structural repair through the formation of granulation tissue (Martin et al., 2003). The vascular endothelial growth factor (VEGF), the major angiogenic and vasculogenic mediator is necessary for quick and effective tissue repair (Jozkowicz et al., 2003). VEGF improves angiogenesis during wound healing by stimulating the migration of endothelial cells through the extracellular matrix (Ferrara, 1999). The higher expression of VEGF favours the more positive expression of CD-31 in curcumin treated wounds than control, a specific marker of endothelial cells confirmed by immunohistochemistry analysis in our study. Motterlini et al., 2000 also observed that vascular endothelial cells treated with curcumin prevented oxidant mediated injury by increased heme oxygenase production. The present study is also accordance with previous workers, the more expression of endothelia cell marker protein CD-31 was observed on day 7 and 14 (Fig. 6).

In conclusion, the treatment of cutaneous excision wounds in rats with curcumin ointment demonstrated a potent pro-healing activity which may be attributed to its proinflammatory in early stage (TNF- $\alpha$ ), antiinflammatory effects by modulating cytokines (IL-10) and more growth factor production (TGF- $\beta 1$ ) and better angiogenesis thereby, favoring a fast and early healing process in treatment group.

\section{Acknowledgment}

The authors are thankful to the Director, Indian Veterinary Research Institute, Izatnagar, Uttar Pradesh, India, for providing necessary facilities and support for conducting present experiment.

\section{Conflict of interest statement}

The authors declare that there are no conflicts of interest.

\section{References}

Aggarwal, B.B. 2003. Signalling pathways of the TNF superfamily: a double-edged sword. Nat. Rev. Immunol., 3: 745-56.

Aggarwal, B.B. and Shishodia, S. 2004. Suppression of the nuclear factor-kappa $B$ activation pathway by spice-derived phytochemicals: reasoning for seasoning. Ann. N. Y. Acad. Sci., 1030: 
434-441.

Bharti, A.C., Donaton, N., Singh, S. and Aggarwal, B.B. 2003. Curcumin (diferuloylmethane) down-regulates the constitutive activation of nuclear factorkappa B \& I kappa B alpha kinase in human multiple myeloma cells, leading to suppression of proliferation and induction of apoptosis. Blood, 101(3): 1053-62.

Braiman-Wiksman L, Solomonik I, Spira R and Tennenbaum T. 2007. Novel insights into wound healing sequence of events. Toxicol Pathol., 35(6): 767-79

Desmouliere, A., Geinoz, A., Gabbiani, F. and Gabbiani, G. 1993. Transforming growth factor-beta 1 induces alphasmooth muscle actin expression in granulation tissue myofibroblasts and in quiescent and growing cultured fibroblasts. J. Cell. Biol. 122: 103-111

Dudhgaonkar, S.P. 2004. Studies on interaction of iNOS and COX-2 inhibitors in inflammation and pain. $\mathrm{PhD}$ thesis submitted to the Division of Pharmacology, IVRI, Izatnagar, p79.

Ferrara, N. (1999). Molecular and biological properties of vascular endothelial growth factor. J. Mol. Med., 77: 527543

Franscis Strodtbeck. 2001. Physiology of wound healing. Newborn and Infant Nursing Reviews., 1(1): 43-52

Gopinath, D., Ahmed, M.R., Gomathi, K., Chitra, K., Sehgal, P.K. and Jayakumar, R. 2004. Dermal wound healing processes with curcumin incorporated collagen films. Biomaterials, 25(10): 1911-1917.

Guide for the Care and Use of Laboratory Animals. 1996. Institute of Laboratory Animal Resources, Commission on life Science, National Research Council. Published by National Academic Press, Washington D.C., USA.
Gurtner, G.C., Werner, S., Barrandon, Y. and Longaker, M.T. 2008. Wound repair and regeneration. Nature, 15: 314-321.

Hunt, T.K., Hopf, H.a nd Hussain, Z. 2000. Physiology of wound healing. Adv. Skin Wound Care, 13: 6-11.

Jagetia, G.C. and Rajanikant, G.K. 2005. Curcumin treatment enhances the repair and regeneration of wounds in mice exposed to hemibody gamma irradiation. Plastic and Reconstructive Surgery, 115(2): 515-528.

Kim, Y.S., Ahn, Y., Hong, M.H., Joo, S.Y., Kim, K.H., Sohn, I.S., Park, H.W., Hong, Y.J., Kim, J.H., Kim, W., Jeong, M.H., Cho, J.G., Park, J.C. and Kang, J.C. 2006. Curcumin attenuates inflammatory responses of TNF-alphastimulated human endothelial cells. $J$. Cardiovasc. Pharmacol., 50(1): 41-9.

Mani, H., Sidhu, G.S., Kumari, R., Gaddipati, J.P., Seth, P. and Maheshwari, R.K. 2002. Curcumin differentially regulates TGF- $\square$ 1, its receptors and nitric oxide synthase during impaired wound healing. BioFactors, 16: 29-43.

Motterlini, R., Foresti, R., Bassi, R. and Green, C.J. 2000. Curcumin, an antioxidant and anti-inflammatory agent, induces heme oxygenase- 1 and protects endothelial cells against oxidative stress. Free Radical Biol. Med., 28(8): 1303-1312.

Nadkarni, K.M. 1976. Curcuma longa. In: Nadkarni, K.M. (Ed.), Indian Materia Medica. Popular Prakashan Publishing Company, Bombay, pp.414-416.

Quaglino, D., Nanney, L.B. Kennedy, R. and Davision, J.M. 1990. Transforming growth factor-bata stimulates wound healing and modulates extracellular matriz gene expression in pig skin excisional wound healing models. Lab Invest., 63: 307-319

Ribbons, K.A., Thompson, J.H., Liu, X., 
Pennline, K., Clark, D.A.,and Miller, M.J.(1997). Antiinflammatory properties of interleukin-10 administration in hapten-induced colitis. European J. Pharmacol., 323: 245-254.

Sidhu, G.S., Singh, A.K., Thaloor, D., Banaudha, K.K., Patnaik, G.K., Srimal, R.C., Maheshwari, R.K. 1998. Enhancement of wound healing by curcumin in animals. Wound Repair and Regen., 6: 167-177

Sidhu, G.S., Mani, H. and Gaddipati, J. P. 1999. Curcumin enhances wound healing in streptozotocin induced diabetic rats and genetically diabetic mice. Wound Repair Regen. 7: 362374.
Sidhu, G.S., Mani, H. and Gaddipati, J. P. 2002. Curcumin differentially regulates TGF-beta-1, its receptors and nitric oxide synthase during impaired wound healing. Biofactors, 16: 29.

Singer, A.J. and Clark, R.A.F. 1999. Cutaneous wound healing. N. Engl. J. Med., 341: 738-46.

Varga, J., Rosenbloom, J. and Jimenez, S.A. 1987. Transforming growth factor beta (TGF beta) causes a persistent increase in steady-state amounts of type I and type III collagen and fibronectin mRNAs in normal human dermal fibroblasts. Biochem. J., 247(3): 597604.

\section{How to cite this article:}

Raju Prasad, Dhirendra Kumar, Vinay Kant, Surendra K. Tandan and Dinesh Kumar. 2017. Curcumin Enhanced Cutaneous Wound Healing by Modulating Cytokines and Transforming Growth Factor in Excision Wound Model in Rats. Int.J.Curr.Microbiol.App.Sci. 6(7): 22632273. doi: https://doi.org/10.20546/ijcmas.2017.607.266 